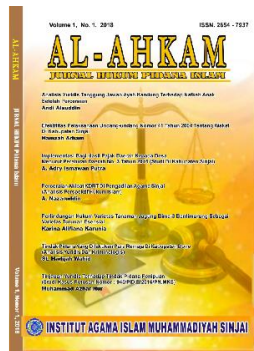

\title{
Wanita Karir Sebagai Dasar Penggunaan Alat Kontrasepsi Spiral (Analisis Maqasid al-Syariah dan Gender)
}

\author{
Ilnawati $^{1}$, Misbahuddin ${ }^{2}$, Mukhtar Lutfi ${ }^{3}$ \\ ${ }^{1}$ Universitas Islam Negeri Alauddin, Makassar \\ ${ }^{2}$ Universitas Islam Negeri Alauddin, Makassar \\ ${ }^{3}$ Universitas Islam Negeri Alauddin, Makassar \\ E-mail: ilnawatibakry@gmail.com,Tlp:+6282336620055
}

\begin{abstract}
Abstrak
Tujuan penelitian ini untuk mendeskripsikan apakah karir dapat menjadi alasan yang dibenarkan dalam Islam untuk menunda kehamilan yang ditinjau dari Maqasid alSyari'ah dan kesetaraan gender. Diperlukan untuk membahas bagaimana pandangan Islam mengenai wanita karir, pandangan Islam mengenai penggunaan alat kontrasepsi terkhusus kontrasespi spiral, dan bagaimana analisis Maqasid al-Syari'ah dan Gender memandang hal ini. Penelitian ini merupakan penelitian kualitatif, jenis penelitian adalah library research dan menggunakan metode pendekatan historis dan normatif. Metode pengumpulan data yang digunakan adalah studi literatur. Hasil penelitian menunjukan bahwa; Wanita karier yang berkecimpung di ranah publik ada yang mampu menyeimbangkan perannya di ranah domestik(rumah) pula tetapi ada yang tidak mampu menyeimbangkan kedua. Bagi pasangan suami istri yang dikhawatirkan tidak mampu mampu menyeimbangkan perannya di salah satu ranah maka pilihan untuk menunda kehamilan sebagai salah satu alternatif untuk meringankan beban peran yang dijalankan wanita. Perlu diingat kembali bahwa alasan penundaan kehamilan haruslah sesuai dengan alasan yang dibenarkan agama dengan mempertimbangkan kemaslahatan bersama dan salah satu pihak terutama wanita yang akan menjalani peristiwa kehamilan/melahirkan. Alasan maslahat menjadi salah satu argumen kebolehan untuk melakukan kontrasepsi karena pada dasarnya kontrasepsi adalah pilihan terakhir jika seorang wanita mengalami suatu keadaaan yang tidak memungkinkan untuk melanjutkan dalam menghasilkan keturunan.Adapun pemakaian kontrasepsi berbentuk spiral atau dikenal dengan istilah (UID). Kontrasepsi ini bersifat temporal dan dapat dihentikan penggunaannya. Karena bersifat temporal maka penggunaan ini dibolehkan dalam Islam selagi tidak mencegah kehamilan secara permanen.
\end{abstract}

Kata Kunci: Wanita Karir, Alat Kontrasepsi Spiral, Maqasid al-Syariah dan Gender.

\section{Pendahuluan}

Perkembangan zaman dan modernisasi berbagai bidang, mengubah gerak dan aktivitas wanita memberikan pengaruh terhadap ideologi dan pandangan wanita terhadap peran yang mereka lakoni. Jika dahulu wanita hanya beraktivitas di lingkungan rumah saja dan menangani pekerjaan domestik, maka wanita sekarang banyak yang sudah melakukan aktivitas berkarir dan mandiri dari segi ekonomi. Peran dan tugas pada area domestik memang tidak semestinya dijadikan tolak ukur peran wanita dalam beraktivitas. 


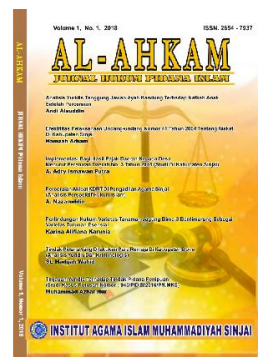

Para wanita saat ini lebih kritis dalam menyuarakan apa saja yang menjadi haknya. Wanita berpeluang memasuki seluruh aspek dalam kehidupan bermasyarakat baik itu politik, ekonomo, sosial, maupun budaya.

Peran wanita dalam berbagai aspek dalam kehidupan masyarakat menjadi bentuk nyata bahwa tidak ada batasan bagi siapapun berkarya dan memberikan manfaat tidak memandang jenis kelamin dan kepentingan lain. Hal ini tentunya berlaku pula bagi wanita yang telah berkeluarga. Wanita dapat menjalankan perannya baik di dalam lingkup keluarga maupun di lingkup bermasyarakat.Bagi pasangan suami istri tentunya memiliki keinginan untuk memiliki keturunan yang akan tetapi ada pasangan yang memilih untuk menunda memiliki keturunan karena disibukkan dengan kegiatannya karirnya di luar rumah.

Berdasarkan pertimbangan tersebut, istri yang sekaligus menjadi wanita karir memilih untuk menunda kehamilannya dengan menggunakan alat kontrasepsi. Ada banyak macam alat kontrasepsi yang dapat digunakan untuk menunda kehamilan. Salah satunya alat kontrasepsi spiral yang merupakan prosedur kontrasepsi yang dipasang dalam rahim.Peran wanita merupakan bagian dari isu gender yang masih digaungkan oleh beberapa kalangan. Perkembangan pemikiran menjadikan perempuan menuntut hak berkarya di berbagai bidang sebagaimana yang dilakukan laki-laki. Adanya wanita karir adalah hasil dari teori gender bahwa ada peran kodrati yang memang telah memiliki porsi masing-masing dan ada peran yang tidak baku dan berpeluang untuk mengalami perubahan.

Pada dasarnya melakukan kontrasepsi memiliki beberapa pendapat dalam hukum Islam. Kadangkala berstatus mubah, haram, makruh, wajib, mandub dilihat dari situasi dan kondisi yang dialami suatu keluarga. Tentunya hal ini tidak jauh-jauh dari pembahasan kemaslahatan. Pertimbangan maqasid al-Syari'ah menghantarkan kepada kemaslahatan bersama. Maka penting untuk melihat kemaslahatan apa yang diinginkan dalam memilih langkah melakukan kontrasepsi.

\section{Metode}

Metode penelitian yang digunakan adalah penelitian pustaka (library research) dan bersifat kualitatif. Sumber data yang dipergunakan dalam penelitian ini bersumber dari data primer dan sekunderdan menggunakan metode pendekatan sosiologi-yuridis dan normatif. Metode pengumpulan data yang digunakan adalah studi literatur. Teknik pengolahan data pada penelitianiniyaitu, melaluiediting, classifying, analysing, dan concluding.

\section{Hasil dan Pembahasan}

\section{A. Wanita Karir dalam Islam}

Al-Qur'an mengistilahkan wanita dengan kata النسآء dang berarti perempuan yang telah dewasa atau istri dan istilah الانثى dengan arti wanita pada umumnya (Hamid Laonso dan Muhammad Jamil, 2005: 77). Perbedaan kata dalam istilah ini tidak sampai menghilangkan substansi definisi perempuan atau wanita secara utuh tetapi mencoba memaknai lagi hakikat yang dimiliki oleh perempuan.

Menurut Kamus Besar Bahasa Indonesia istilah wanita ialah perempuan dewasa. Perempuan yang masih kecil yaitu anak-anak tidak diistilahkan dengan wanita. Kata karir 


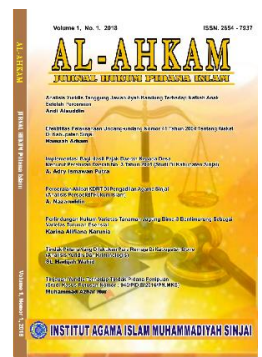

memiliki dua arti: pertana, karir yaitu pengembangan dan kemajuan dalam kehidupan, pekerjaan, dan sebagainya; kedua, karir berarti pekerjaan yang memberikan harapan untuk maju (Kementrian Pendidikan dan Kebudayaan, 2021). Maka dari itu, karir biasanya dikaitkan dengan uang dan kuasa. Tetapi pencapaian yang lebih luas yaitu karir merupakan karya yang dihasilkan oleh seseorang dan berdampak bagi lingkungan sekitarnya. Berkarya tidak memandang siapapun. Manfaat juga bisa diberikan dari lakilaki maupun perempuan. Tidak memandang perbedaan jenis kelamin.

Apabila kata "wanita dan "karir" disatukan, maka memberikan makna bahwa wanita karir adalah wanita dewasa yang menekuni kegiatan yang bertujuan untuk mendapatkan perkembangan dan kemajuan dalam kehidupan. Oleh karena itu dapat dirumuskan bahwa wanita karir adalah wanita yang berkecimpung dalam pekerjaan yang dilandasi dengan keahlian tertentu yang ia miliki bertujuan mencapai kemajuan dalam kehidupan, pekerjaan, ataupun jabatan. Umumnya, karir wanita berada di sektor luar rumah sehingga wanita karir tergolong mereka yang berkiprah di sektor publik. Dikarenakan karir adalah usaha yang membutuhkan perkembangan dan kemajuan kehidupan, dibutuhkan kapasitas dan keahlian yang hanya bisa diraih dengan cara tertentu.

Kebutuhan menjadi salah satu alasan wanita memilih untuk memperluas kemampuannya. Memenuhi kebutuhan yang ada dalam rumah menjadi alasan yang paling banyak dialami wanita sehingga mengharuskannya berkarir di luar rumah. Wanita yang berkecimpung dalam sebuah karir terkadang mereka mencapai kenyamanan dan menjadikannya suatu rutinitas yang mereka cintai dan tidak ingin melepaskan rutinitas itu bahkan wanita lebih memprioritaskan karirnya dibandingkan aspek kehidupan apapun di hidupnya. Selain kebutuhan pokok, ada beberapa motivasi yang mendorong wanita terjun ke dunia karir antara lain:

a) Pendidikan: pendidikan dapat melahirkan perempuan yang berkarir dalam berbagai lapangan pekerjaan. Kemajuan wanita di sektor pendidikan yang membuat wanita banyak yang tercerahkan melalui pendidikan tidak lagi merasa terpuaskan apabila hanya menjalankan perannya di rumah saja (Hasan, M. Ali, 1998: 193).

b) Alasan ekonomis. Wanita memilih berkarir di luar rumah agar tidak menggantungkan ekonomi keluarga pada suami, walaupun suami mampu memenuhi kebutuhan rumah tangga, adanya motivasi dari perempuan selagi ada kemampuan sendiri tidak selalu meminta kepada suami.

c) Mengumpulkan kekayaan sebanyak-sebanyaknya. Hal ini biasanya dilakukan oleh perempuan yang memegang prinsip bahwa kekayaan adalah segalanya.

d) Mengisi waktu luang. Ada beberapa perempuan yang merasa bosan berdiam di rumah karena tidak mempunya kesibukan dengan urusan rumah tangga. Hal ini kadang dirasakan oleh wanita yang belum berkeluarga.

e) Mencari ketenangan dan hiburan. Beberapa perempuan menjadikan karir sebagai hiburan untuk mengalihkan dirinya dari kemelut atau problema yang sedang mereka hadapi. Dengan melakukan kesibukan yang bermanfaat kadang berkarir dapat menghibur diri dan membawa pemikiran yang positif (Wakirin, 2017). 


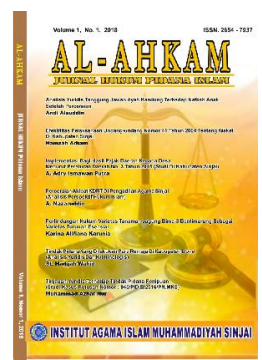

f) Mengembangkan bakat. Mengasa diri mencapai karir tertentu akan melahirkan wanita yang mampu menemukan bakatnya bahkan larut dalam karir tertentu. Hal ini juga mampu memberikan dampak positif bagi wanita (Huzaemah Tahido Yanggo, 2010: 21)

Sebelum Islam datang, peradaban besar di dunia seperti Yunani, Romawi, India, dan Cina yang pada saat itu perempuan masih dipandang rendah layaknya barang tidak bernyawa dan diperlakukan semena-mena. Bangsa-bangsa besar terdahulu memiliki pandangan bahwa perempuan itu lemah dan emosional dalam berpendapat. Oleh karenanya mereka meremehkan wanita dan tidak mendengarkan pendapat kaum wanita (Khairiyah Husain, 2005: 2). Arab Jahiliyah melakukan hal yang sama seperti bangsabangsa besar sebelum Islam. Para kaum laki-laki tidak menampakkan ketidaksenangannya dengan kelahiran anak-anak perempuan bahkan ada yang mengubur hidup-hidup bayi perempuan. Kemudian Islam datang menempatkan kaum wanita di posisi yang sangat mulia, mengangkat derajat perempuan dari keterpurukan.

Al-Qur'an memberikan keterangan mengenani peran dan fungsi wanita dalam kehidupan. Terdapat beberapa surah dalam Al-Qur'an yang khusus membahas mengenai perempuan seperti salah satu nama dalam surah Al-Qur'an yang bertajuk wanita dan Allah menamai surah itu dengan nama $\mathrm{An}$-Nisa' yang artinya para wanita. Hal ini membuktikan bahwa Islam menaruh perhatian yang besar terhadap wanita dan mengangkat harkat dan martabat wanita. Beberapa peran dan fungsi wanita yang diterangkan dalam agama Islam yakni sebagai berikut: (Farida Husin, 2015)

1. Wanita sebagai Ibu

Islam memandang dan memposisikan wanita sebagai ibu dan posisi ini adalah posisi yang luhur dan sangat terhormat. Ibu adalah satu di antara dua orang tua yang memiliki peran yang sangat penting di kehidupan setiap manusia. Dalam kasih ibulah setiap individu dirawat dan dibesarkan dengan kesabaran dan cinta yang terhingga. AlQur'an secara tegas memerintahkan setiap manusia untuk mengapresiasi ibu atas jasajasanya yang tak terhingga dengan berbuat baik kepadanya. Hadis Nabi Saw. Juga memberikan apresiasi yang besar terhadap kedua orang tua, terkhusus ibu.

2. Wanita sebagai istri

Selain menjadi ibu, Islam memberikan keterangan bahwa peran sehari-hari wanita adalah sebagai istri. Q.S Al-Baqarah/2:187 menerangkan,

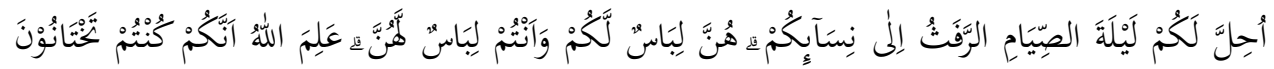

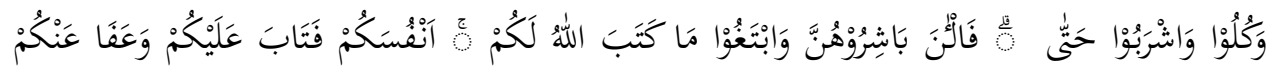

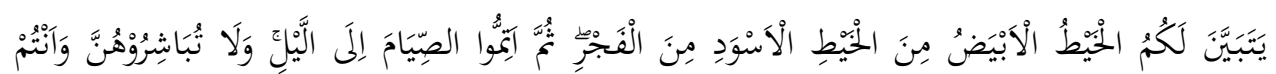

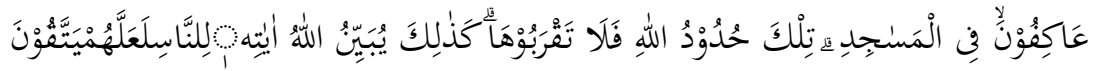

Terjemahnya: 


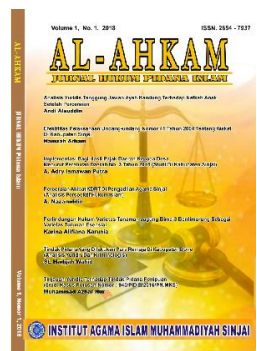

Al-Ahkam

Jurnall Hukum Pidana Islam

Volume 3, No. 1, 2021

ISSN (print) : 2654-7937

ISSN (online) : 2715-0313

Homepage : http://journal.iaimsinjai.ac.id/index.php/al-ahkam/index

"Dihalalkan bagimu pada malam hari puasa bercampur dengan istrimu. Mereka adalah pakaian bagimu, dan kamu adalah pakaian bagi mereka. Allah mengetahui bahwa kamu tidak dapat menahan dirimu sendiri, tetapi Dia menerima tobatmu dan memaafkan kamu. Maka sekarang campurilah mereka dan carilah apa yang telah ditetapkan Allah bagimu. Makan dan minumlah hingga jelas bagimu (perbedaan) antara benang putih dan benang hitam, yaitu fajar. Kemudian sempurnakanlah puasa sampai (datang) malam. Tetapi jangan kamu campuri mereka, ketika kamu beriktikaf dalam masjid. Itulah ketentuan Allah, maka janganlah kamu mendekatinya. Demikianlah Allah menerangkan ayat-ayat-Nya kepada manusia, agar mereka bertakwa." (Kementrian Agama Republik Indonesia, 2021)

Suami istri kedekatan dan fungsinya bagaikan pakaian yang melekat di tubuh pemakainya yaitu saling menutupu kekurangan dan saling melindungi. Islam memandang perkawinan sebagai ikatan yang kuat dalam rangka mensejahterahkan manusia serta melanjutkan kelangsungan hidup manusia melalu regenerasi dalam sistem yang sehat.

3. Wanita sebagai pribadi dan anggota masyarakat

Masyarakat adalah sekelompok individu yang saling berinteraksi dalam tujuan memenuhi kebutuhan bersama. Setiap individu membentuk keluarga dan keluargakeluarga itu adalah komponen masyarakat. Tak dapat dipungkiri masyarakat lebih kurang separuh anggotanya adalah wanita. Oleh karena itu, wanita menjadi penguat dan pengokoh dalam mencapai harapan dan cita-cita bermasyarakat dan wanita juga penentu dari kesuksesan bermasyarakat. Moralitas sebagai sendi terpenting bermasyarakat sangat ditentukan dari peran wanita dalam bermasyarakat tetapi hal ini tidak boleh dipahami bahwa wanita satu-satunya yang memegang tanggung jawab dalam kehidupan bermasyarakat. Hal ini menerangkan bahwa wanita memiliki peran yang besar dalam sendi kehidupan sosial.

Melihat keadaan perempuan saat ini, ada empat kriteria yang melekat pada wanita dalam kiprahnya, yaitu:

1. Perempuan dengan tingkat excellent smart dan the best (perempuan yang berkualitas yang mampu dan berhasil mengelolah rumah tangga sekaligus meraih karirnya dengan sukses)

2. Perempuan yang sukses di wilayah domestik rumah tangga adalah perempuan yang berhasil membina rumah tangga saja karena merasa kurang mampu dalam hal karir.

3. Perempuan yang sukses berkari namun terbengkalai dalam urusan rumah tangga. Bahkan sampai pada tahap hanya mengejar karir tetapi ruma tangganya tidak terurus bahkan rumah tangga dianggap penghambat kemajuannya dalam berkarir.

4. Perempuan yang tidak mampu dalam berkarir dan berumah tangga. Keduanya tidak mencapai keberhasilan. Hal ini tidak boleh terjadi karena perempuan diposisikan sebagai maqam yang sedemikian mulai (Nur Aini Latifah, 2008).

Allah menciptakan manusia diiringi dengan kebutuhan manusia sebagai makhluk yang mempunyai kebutuhan berupa makan, minum, pakaian, tempat tinggal, dan keturunan. Allah menyediakan seluruh kebutuhan itu tetapi manusia harus berusaha memperoleh kebutuhan itu semua. Allah berfirman dalam Q.S Al-Jumu'ah/62:10 


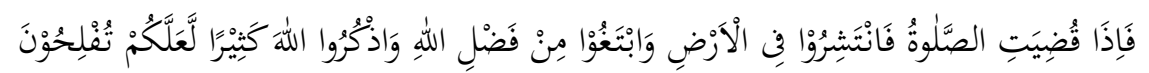

Terjemahnya:

"Apabila salat telah dilaksanakan, maka bertebaranlah kamu di bumi; carilah karunia Allah dan ingatlah Allah banyak-banyak agar kamu beruntung".

Maka dari itu manusia harus bekerja. Dalam kondisi seperti itu, wanita dapat melakukan usaha pekerjaan dan terjun ke dalam suatu profesi untuk memenuhi kebutuhan hidup serta keluarganya jika dalam suatu keluarga tidak mampu melakukan usaha kecuali wanita dalam keluarga itu. Sementara pada kesempatan lain seorang wanita disunnahkan untuk melakukan kegiatan profesi yang manakalah kegiatan profesi itu dilakukan sejalan dengan tanggung jawabnya dalam keluarga dan membantu suami, ayah, atau saudaranya yang tidak mampu mencukupi kebutuhan keluarga.

Permasalahan timbul yang berkaitan dengan keterlibatan wanita dalam dunia profesi yang ruang geraknya berada di sektor publik. Sedangkan di sisi lain wanita sebagai penanggung jawab rumah tangga. Abbas Mahmud al-Aqqad tidak memperbolehkan wanita (istri) bekerja di luar rumah, alasannya karena pria diberi kemampuan berlebih untuk menghadapi realita di luar rumah daripada perempuan. Maka dari itu wanita bersinggasana di dalam rumah meskipun wanita memiliki kesanggupan secara fisik maupun mental yang sama dengan pria tetapi dalam kondisi tertentu wanita harus tetap di rumah karena wanita mengalami kehamilan, melahirkan, dan menyusui. Kecuali wanita terpaksa harus mencari nafkah sendiri.

Mustafa al-Siba'i berpendapat membolehkan wanita berkarir apabila tidak ada seseorang yang menjamin nafkahnya. Itupun hanya pekerjaan tertentu yang wajar dan tidak terlalu beresiko banyak. Wanita lebih utama tinggal di rumah bila memiliki anak.Abdurrahman Taj berpendapat bahwa apabila seorang istri bekerja seharian atau sebagian waktu kemudian pada malam hari menggunakan sisa waktunya mengurus keluarga dan apabila suami rela akan hal tersebut, gugurlah haknya dalam menahan istri tinggal di rumah dan wajib memberikan istri nafkah, sebaliknya manakal suami tidak rela istri bekerja di luar rumah maka ia tidak wajib memberikan istri nafkah. Bahkan bila suami awalnya rela istri bekerja lantas berubah pikiran untuk mencegah istrinya bekerja kemudian istrinya menolak berhenti bekerja, maka gugurlah kewajiban suami memberi nafkah.Al-Hatimi berpendapat bahwa wanita boleh bekerja, bahkan dibolehkan menduduki jabatan strategis penting di masyarakat dengan catatan harus tetap tunduk pada syariat yang menjaga kesuciaannya serta tidak mengabaikan peran utamanya di dalam rumah tangga. Pendapat ini didasari dari partisipasi wanita di zaman Nabi saw. Dalam peperangan misalnya: “ mengangkat atau menyediakan air minum bagi para prajurit, memasak atau menyediakan makanan, menjaga atau merawat prajurit yang sakit dan memelihara kendaraaan, menjadi mata-mata dalam peperangan, menjahit pakaian dan sebagainya".Al-Sakhawi mengatakan bahwa wanita-wanita yang memiliki keahlian tertentu semestinya diabdikan kepada masyarakat agar kemanfaatannya dapat dirasakan orang banyak. Pendapat ini juga sama seperti pendapat Jamal ad-Din Muhammad Mahmud bahwa wanita berhak mendapatkan kesempatan untuk bekerja di sektor publik 


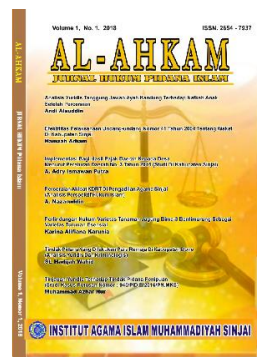

Al-Ahkam

Jurnall Hukum Pidana Islam

Volume 3, No. 1, 2021

ISSN (print) : 2654-7937

ISSN (online) : 2715-0313

Homepage : $\underline{\text { http://journal.iaimsinjai.ac.id/index.php/al-ahkam/index }}$

apabila yang bersangkutan membutukan pekerjaan dan pekerjaan membutuhkan kepandaian yang ia miliki (Muhammad Albar, 1999: 50).

Pendapat ulama ini mewakili bahwa Islam menyamaratakan peran dan fungsi wanita dengan laki-laki. Wanita memiliki peluang yang sama dalam berusaha dan memenuhi kebutuhannya serta memiliki hak yang sama dalam rangka mengembangkan diri dan kehidupan yang mereka jalani. Tidak membatasinya dengan stigma-stigma yang membatasi peran perempuan dalam berkarya.

\section{B. Kontrasepsi dalam Pandangan Islam}

Kontrasepsi sebagai upaya penundaan kehamilan salah satu esensi diadakannya gerakan Keluarga Berencana (KB) yang dipakai oleh Badan Koordinasi Keluarga Berencana Nasioanl (BKKBN). Istilah KB ini memiliki arti yang sama dengan istilah yang dipakai di ranah internasional. Misalnya family planning. Keluarga Berencana dapat bermakna Tanzim al-Nasl (Pengaturan keturunan/kelahiran) atau Tahdid al-Nasl (pembatasan kelahiran) (Suhaedah, 2013: 16).

Salah satu metode pengaturan jarak kehamilan di Indonesia yaitu dengan menekan jumlah anak atau menjarangkan kelahiran dilihat dari situasi dan kondisi suami istri. Istilah pengaturan ini disebut dengan Birth Control yaitu dengan mengontrol kehamilan istri dalam membatasi keturunan. Salah satu metode yang digunakan yaitu dengan melakukan prosedur kesehatan untuk mengatur pencegahan kehamilan.

Kontrasepsi berasal dari kontra yang berarti mencegah atau melawan, konsepsi adalah pertemuan sel telur yang matang dan sel sperma yang mengakibatkan kehamilan. Setelah digabungkan menjadi kata kontrasepsi yang bermakna mencegah terjadinya kehamilan yang diakibatkan pertemuan atara sel telur yang matang dengan sel sperma (Ikhwani Ratna \& Irdayanti, 2012).

Kontrasepsi adalah pencegahan kehamilan dengan melakukan prosedur kesehatan seperti dengan mendapatkan suntikan, kontrasepsi oral, kontrasepsi intravaginal, kondom, alat kontrasepsi dalam rahim (AKDR) atau intrauterine device (I.U.D), operasi tubektomi atau vaksetomi atau dengan cara konvensional.

Pada prosedur penggunaan kontrasepsi, ada beberapa jenis yaitu dengan kontrasepsi hormonal oral, kontrasepsi hormonal jangka panjang, AKDR (alat kontrasepsi dalam rahim) atau IUD (intra uterine device), cara-cara sederhana seperti menggunakan metode penghalang, senggama terputus, kondom, diafragma, kondom wanita, spermisida, tisu vaginal, pantang berkala, dan metode kontap (kontrasepsi mantap), meliputi MOW (Metode Operasi Wanita), dan MOP (Metode Operasi Pria) (Hartanto, 2004).

1. Kontrasepsi Hormonal Oral

Kontrasepsi ini mengandung estrogen atau progestin atau gabungan estrogen dan progestin.Kontrasepsi hormonal oral dewasa ini banyak tersedia untuk penggunaan klinik. Preparat-preparat ini bervariasi secara kimiawi dan banyak mempunyai kemiripan satu sama lain, tetapi tetap mempunyai perbedaan yang jelas(Staf Pengajar Departemen Farmakologi, 2004).

Tipe sediaan kontrasepsi hormonal oral, yaitu:

a. Pil kombinasi estrogen dan progestin; 


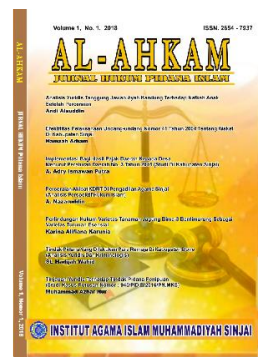

Al-Ahkam

Jurnal Hukum Pidana Islam

Volume 3, No. 1, 2021

ISSN (print) : 2654-7937

ISSN (online) : 2715-0313

Homepage : $\underline{\text { http://journal.iaimsinjai.ac.id/index.php/al-ahkam/index }}$

b. Pil sekuensial, pemberian estrogen yang disusul oleh kombinasi estrogen danprogestin;

c. Pemberian progestin yang terus-menerus tanpa disertai pemberian estrogen.

Mekanisme kerja kontrasepsi hormonal oral:Kombinasi estrogen, progestin, dan sediaan sekuensial bekerja terutama untuk mencegah ovulasi. Sediaan kombinasi yang mengandung estrogen dan progestin juga menimbulkan perubahan-perubahan pada mucus serviks, endometrium dan motilitas tuba falopii serta sekresinya(Soetjiningsih, 1997). Pil Kombinasi:

a. Bekerja melalui inhibisi umpan balik pada hipotalamus untuk menekan GnRH \& sekresi gonadotropin plasma sehingga memblok ovulasi.

b. Menyebabkan endometrium tidak siap menerima janin dengan mengubah motilitas tuba fallopi sehingga mengubah komposisi mukus serviks.

Jika obat diberikan secara tunggal, efeknya menurun sehingga tidak menghambat ovulasi. Pil progesteron bekerja dengan cara menyebabkan endometrium tidak siap menerima janin dengan mengubah motilitas tuba fallopi sehingga mengubah komposisi mukus serviks sehingga hanya memblok $\pm 25 \%$ ovulasi(Staf Pengajar Departemen Farmakologi, 2004).

Efek samping secara umum. Penggunaan sediaan kombinasi atau sekuensial dalam waktu yang lama akan menekan fungsi ovarium. Gambaran makroskopis ovarium tampak sebagai suatu keadaan yang relative inaktif, terdapat sedikit perkembangan folikel dan korpora lutea, dengan folikel-folikel yang lebih besar, udema pada stroma dan tidak dijumpai adanya gambaran ovulasi lain, seperti yang terlihat pada wanita normal (Ali Baziad, 2002).

Pada umumnya, jumlah estrogen endrogen yang diekskresikan dalam urin berkurang dibandingkan wanita normal yang sedang menstruasi, dan ekskresi pregnandiol tidak selalu meningkat pada fase selanjutnya dari siklus.Tidak diketahui apakah ekskresi pregnandiol yang meningkat disebabkan oleh tidak terjadinya ovulasi atau karena korpora lutea terbentuk tanpa ovulasi. Meskipun pernah dilaporkan adanya folikel sistik pada pasien yang makan pil kontrasepsi, ovarium biasanya menjadi lebih kecil meskipun sebelum terapi sudah membesar(Staf Pengajar Departemen Farmakologi, 2004).

Sedangkan efek samping kontrasepsi oral yang hanya mengandung progestin saja:

a. Sama seperti efek samping kombinasi tetapi jarang terjadi

b. Gangguan siklus menstruasi disertai pendrahan abnormal, haid berikutnya bisa terjadi beberapa hari lebih cepat atau lebih lambat dari yang diperkirakan. Jika haid tidak terjadi dalam waktu 3 mingg evaluasi adanya kehamilan (Soetjiningsih, 1997).

2. Kontrasepsi Hormonal Jangka Panjang

a. Suntikan KB, Kontrasepsi suntik adalah kontrasepsi hormonal jenis suntikan yang dibedakan menjadi duamacam yaitu DMPA (depot medroksiprogesterone asetat) dan kombinasi.Suntik DMPAberisi depot medroksiprogesterone asetat yang diberikan dalam suntikan tunggal $150 \mathrm{mg} / \mathrm{ml}$ secara intramuscular (IM) setiap 12 minggu.Efek sampingpenggunaan suntik DMPA adalah gangguan haid, penambahan berat badan, kekeringan vagina, menurunkan libido, gangguan emosi, sakit kepala, nervotaksis dan jerawat. Gangguan haid yang sering ditemukan berupa siklus haid yang memendek atau memanjang, perdarahan banyak atau sedikit, 


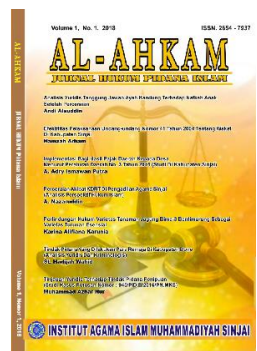

Al-Ahkam

Jurnall Hukum Pidana Islam

Volume 3, No. 1, 2021

ISSN (print) : 2654-7937

ISSN (online) : 2715-0313

Homepage : $\underline{\text { http://journal.iaimsinjai.ac.id/index.php/al-ahkam/index }}$

perdarahan yang tidak teratur atau perdarahanbercak (spotting), tidak haid sama sekali (amenore)(Ali Baziad, 2002).

b. Susuk KB (Nortplant atau Implant). Susuk KB yang diperkenalkan di Indonesia sejak 1982 dapat diterima masyarakat sehingga Indonesia merupakan negara terbesar pemakai norplant. Susuk KB disebut alat KB bawah kulit (AKBK).Kini sedang diuji coba susuk KB satu kapsul yang disebut implanon (Hellen Varney, 2006) Pemasangan norplant (susuk KB) sederhana dan dapat diajarkan, tetapi masalah mencabut susuk KB memerlukan perhatian karena sulit dicari metode yang mudah, murah, dan aman. Jumlah yang memerlukan pelayanan pencabutan makin besar; dan dijumpai penyulit dan komplikasi saat mencabut.

3. Alat Kontrasepsi Dalam Rahim (AKRD)/ Intra Uterine Device (IUD)

Alat ini terdiri dari plastik dan tembaga kecil yang dimasukkan ke dalam Rahim. Alat ini akan menghentikan proses pembuahan sel telur di Rahim. AKDR sangat efektif mencegah kehamilan dan bisa dipakai selama 4-5 tahun.Sebaiknya AKDR dipasang setelah 40 hari persalinan karena saat itu mulut rahim masih terbuka dan rahim dalam keadaan lunak.AKDR ditempatkan dalam rongga rahim setinggi mungkin. Alat ini akan diperiksa kembali setelah satu minggu terpasang, kemudian sebulan sekali, lalu tiga bulan sekali, dan selanjutnya setiap enam bulan sekali.

Efek samping AKDR:Biasanya terjadi sedikit perdarahan serta rasa mulas-mulas selama tiga hari.Pemakaian AKDR harus dihentikan jika ibu terus mengalami perdarahan. Siklus haid mungkin akan terganggu, kemudian ada risiko keputihan, dan infeksi jika kebersihan tidak dijaga. Kejang rahim dan rasa tidak enak pada perut bagian bawah mungkin terjadi karena kontraksi rahim sebagai reaksi terhadap AKDR yang merupakan benda asing dalam rahim. Obat analgetik bisa mengatasikeluhan ini (Ali Baziad, 2002).

4. Metode Mantap (Kontrasepsi Mantap)

a. Metode Operasi Wanita (Tubektomi),

Tuba falopi adalah struktur berbentuk pipa yang menjadi jalur perjalanan telur setelah dilepaskan dari indung telur (ovarium). Setiap wanita memiliki tuba falopi sepasang, dua ujungnya melekat di sisi rahim dan dua ujung lainnya terbuka di perut. Panjang masing-masing tabung ini sekitar $10 \mathrm{~cm}$. Tubektomi atau ligasi tuba adalah bedah sterilisasi perempuan di mana tuba falopi disumbat, dipotong atau diklem sehingga telur terhambat untuk bertemu dengan sperma. Hal ini mencegah kehamilan.

Menurut dr Zubairi Djoerban, spesialis penyakit dalam dan guru besar FKUI, boleh tidaknya seorang perempuan menjalani prosedur ini sangat tergantung dari kondisi kesehatan yang bersangkutan. Jika ada infeksi di rongga panggul atau sedang hamil, tidak dibenarkan melakukan prosedur tubektomi.

Tubektomi dilakukan dengan cara operasi yang memerlukan pembiusan. Jika melihat situasi di mana tubektomi tidak dilakukan bersamaan dengan proses melahirkan, maka prosedur yang paling populer saat ini adalah dengan laparaskopi. Laparaskopi dilakukan dengan sedikit menyayat bagian perut, kemudian memasukkan semacam selang kecil untuk meneropong. Setelah saluran telur ditemukan lalu diikat.

Teknik ini membutuhkan pembiusan umum/total, sehingga sebelumnya perlu diperiksa apakah kondisi kesehatan ibu, terutama sistem pernapasan, jantung, dan 


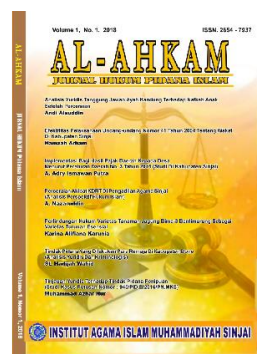

pembuluh darahaman untuk dilakukan pembiusan umum.Kelebihan metode $\mathrm{KB}$ ini adalah angka keberhasilannya dalam mencegah kehamilan paling baik dibandingkan metode KB lainnya, angka keberhasilannya mencapai 99 persen. Metode ini juga aman untuk orang yang berisiko bila memakai metode KB yang bersifat hormonal seperti pil, suntik, atau susuk. Sebenarnya, setelah tubektomi juga dapat dilakukan penyambungan kembali saluran telur dengan teknik operasi khusus menggunakan mikroskop.Kelemahannya adalah karena prosedurnya memerlukan operasi dan pembiusan sehingga terdapat risiko baik dari pembiusan maupun tindakan pembedahannya.

b. Metode Operasi Pria (Vaksetomi)

Vasektomi adalah prosedur bedah sederhana yang menutup tabung penyalur sperma (vas deferens) yang terletak di skrotum sehingga sperma tidak bercampur dengan cairan mani (semen) yang diejakulasi.

Vasektomi dilakukan di bawah bius lokal. Suntikan bius dilakukan pada daerah sekitar skrotum dan kemudian lubang yang sangat kecil dibuat pada $\mathrm{b}$ (vas deferens) dipotong dan ditutup.Efek samping:(1) Sedikit pembengkakan dan memar, namun hal ini dapat dikurangi dengan menggunakan kompres es dan penghilang rasa sakit. Sebuah benjolan seukuran kacang kecil mungkin berkembang di situs operasidan menetap untuk sementara waktu. Ini adalah reaksi penyembuhan alami tubuh dan tidak perlu pengobatan.(2) Kemungkinan infeksi, tetapi mudah diobati dengan antibiotik. Sedikit perdarahan dari pembukaan skrotum. Pada kesempatan yang sangat langka, terutama jika terlibat dalam kerja fisik yang berat, hal ini dapat membentuk pembengkakan di skrotum, tetapi biasanya akan hilang sendiri.

Sebelum membahas pandangan Islam mengenai Kontrasepsi, ada dua hal yang harus diketahui perbedaannya yaitu: menunda kehamilan dan membatasi kehamilan. Menunda kehamilan berarti mencegah terjadinya kehamilan sementara memberikan jarak pada kelahiran sebelum. Sedangkan membatasi kehamilan adalah membatasi kehamilan atau kelahiran anak yaitu membatasi selamanya setelah mendapatkan anak dengan jumlah yang diinginkan (M. Ali Hasan, 1977).

Pada permasalahan kedua, yakni membatasi kehamilan yang dilakukan tanpa alasan yang dibenarkan syari'at tentunya hal ini sudah jelas keharamannya. Kecuali ada keadaaan seorang wanita terkena penyakit ganas yang ada pada rahimnya dan akan membahayakan keselamatan hidup seorang wanita, maka alasan tersebut pembatasan kehamilan dibolehkan.

Sedangkan permasalahan pertama, yaitu penundahan kehamilan tidak dapat dipungkiri adanya kemaslahatan di dalamnya yaitu menjaga kesehatan ibu menjadi salah satu tujuan syari'ah yaitu menjaga jiwa. Menurut Yusuf Qardawi, alasan dalam Islam yang menjadi sebab pelaksaan penundahan kehamilan yang merupakan salah satu metode dalam program Keluarga Berencana yaitu:

1. Mengkhawatirkan kehidupan atau kesehatan ibu apabila hamil dan melahirkan dengan jarak yang berdekatan. Diperlukan untuk menunda kehamilan dengan menggunakan alat kontrasepsi. 


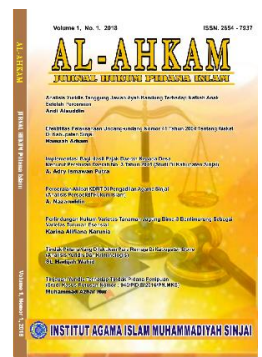

Al-Ahkam

Jurnall Hukum Pidana Islam

Volume 3, No. 1, 2021

ISSN (print) : 2654-7937

ISSN (online) : 2715-0313

Homepage : $\underline{\text { http://journal.iaimsinjai.ac.id/index.php/al-ahkam/index }}$

2. Khawatir terjadi bahaya pada urusan dunia yang terkadang mempersulit peribadatan seperti ketika wanita mengalami nifas yang terlalu sering akan mengurangi waktu beribadah wanita.

3. Mengkhawatirkan anak yaitu terpuruknya kesehatan dan terbengkalainya pendidikan. Apabila tidak diberi jarak dan teralihkan fokusnya mengurus anak yang lahir lebih awal kemudian lahir anak selanjutnya maka ibu akan kewalahan mengurusi kebutuhan anak karena tidak mampu memfokuskan diri mengurusi masing-masing anak (Yusuf Al-Qardhawi, 1993: 272-274).

Kebolehan menggunakan alat kontrasepsi harus didasari dengan niat yang baik, karena keboleh penggunaan kontrasepsi hanya merupakan rukhsah (keringanan) dalam Islam bagi suatu keluarga untuk menerapkan keseimbangan dalam kehidupan keluarga dan bermasyarakat bahkan bernegara serta mengatasi mudharat (kesukaran) dalam memenuhi kebutuhan berumah tangga (A. Rakhmat Rosyadi dan Saroso, 1986: 24).

Abdurrahman Abdullah al-Farisi dalam bukunya Al-Ajwibatu Nafi'ati 'Amil Nasalatil Waqi'ati mengatakan Al-Qur'an tidak menghalangi pasangan suami istri menertibkan kelahiran dan keturunan. Penertiban yang dimaksud ialah memberikan jarak waktu antara kehamilan dan melahirkan dengan kehamilan berikutnya. Hal ini dilakukan untuk memberikan keringanan kepada kaum ibu yang mengalami kesakitan menderita disebabkan peristiwa kehamilan dan melahirkan. Selain menjadi keringanan bagi kaum ibu, penundaan kehamilan hanya dibenarkan bagi keluarga yang kurang mampu memikul kewajibannya sebagai kepala keluarga sehingga istri dan anaknya tidak terurus, baik dari segi kesehatan maupun pendidikan. Karena hal demikian, pengaturan kehamilan/kehamilan sebagai solusi untuk menghilangkan kesusahan dan kemudharatan. Tetapi tidak sekali-kali digunakan untuk tidak melakukan kelahiran karena takut kelaparan (kemiskinan)(A. Rakhmat Rosyadi dan Saroso, 1986: 24).

\section{AnalisisMaqasid al-Syari'ah dan Gender}

Gender adalah kontruksi dan tatanan sosial tentang perbedaan antara jenis kelamin yang mengacu pada hubungan sosial antara laki-laki dan perempuan, atau sifat yang ditetapkan secara sosial maupun budaya. Berdasarkan istilah ini timbul paham mengenai pembagian peran antara laki-laki dan perempuan secara sosial dan budaya. Secara gender, peran didasarkan pada kodrat, sementara dari aspek budaya sangat berpeluang untuk mengalami pertukaran antara laki-laki dan perempuan. Mengenai peran kodrati seperti mengalami menstruasi, hamil, melahirkan, dan menyusui yang dialami wanita adalah peran yang tidak dapat ditukarkan karena hal ini sudah diciptakan sedemikian rupa. Istilah gender mengarah pada makna sosial, adat, agama, budaya, etnik, waktu, tempat, dan kemajuan iptek. Maka gender dapat mengalami konstruksi.

Gender bermaksud memberikan struktur mengenai mana yang kodrati (nature) dan mana yang dapat dibentuk atau konstruk budaya dan sosial (nurture) pada kehidupan relasi perempuan dan laki-laki di wilayah domestik maupun publik (Mansour Fakih, 2007: 3-9). Dengan demikian konsep dan manifestasi relasi gender lebih dinamis dan memiliki keelastisan dengan mempertimbangkan psikososial yang berkembang. Berdasarkan tujuan ini seseorang bisa saja dikategorikan sebagai perempuan secara 


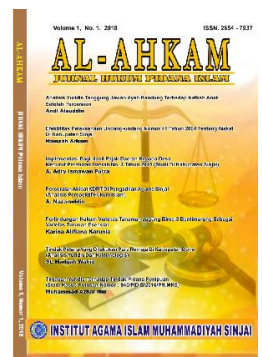

biologis, tetapi dari sudut pandang gender berperan sebagai laki-laki atau sebaliknya. (Komarudin Hidayat, 2008).

Menurut Mansour Fakih konsep tentang perbedaan gender dan peran gender adalah konsep yang paling banyak melahirkan ketidakadilan gender. Indikator nya yaitu ada lima hal:

1. Marginalisasi, bentuk peminggiran terhadap salah satu jenis kelamin umumnya perempuan karena beranggapan bahwa perempuan tidak layak menjadi pemimpin. Marginalisasi sering berujung pada kemiskinan perempuan karena tidak diberikan kesempatan berkarya.

2. Stereotype, stigma negatif terhadap jenis kelamin tertentu umumnya terjadi juga pada perempuan yang berakibat membatasi dan menyulitkan perempuan.

3. Subordinasi, merendahkan jenis kelamin tertentu dan lagi-lagi kebanyakan terjadi pada perempuan seperti pandangan bahwa perempuan tidak berhak bersekolah tinggi.

4. Double/ multi burden yaitu peran bertumpuk yang diberikan kepada perempuan antara peran domestik dan peran publik.

5. Violence, kekerasan terhadap jenis kelamin tertentu dan lagi-lagi kebanyakan terjadi pada perempuan sehingga mengalami pelecehan dan penganiayaan. Indikator keadilan menurut Mansour Fakih ada empat aspek yaitu:

1. Akses atau memiliki kesempatan yang sama untuk memperoleh hak antara lakilaki dan perempuan, misalnya memiliki kesempatan yang sama secara profesionalitas dan transparan dalam bekerja dan memperoleh gaji.

2. Kontrol, dilihat melalui daya pengendalian pemahaman atau pembangunan yang menguntungkan bagi masing-masing jenis kelamin yang memiliki kebutuhan dasar yang sama.

3. Partisipasi, meningkatkan peran serta masing-masing gender dalam beberapa bidang baik itu wilayah domestik maupun publik sehingga aspirasi mereka dapat diwadahi dan tersalurkan.

4. Masing-masing gender merasa mendapatkan manfaat dari pembangunan (Mansour Fakih, 2007: 73).

Keadilan dan kesetaraan gender dalam Islam dilihat dari keterangan Al-Qur'an dan Hadis mengenai peran laki-laki dan perempuan. Prof. Dr. Nasaruddin Umar menerangkan ada beberapa ukuran yang digunakan sebagai pedoman dalam melihat prinsip kesetaraan gender dalam Al-Qur'an. Tolak ukur tersebut antara lain:

1. Laki-laki dan perempuan sama-sama sebagai hamba

Salah satu tujuan penciptaan manusia adalah untuk menyembah kepada Tuhan (QS. Az-Dzariyat/51:56). Dalam kapasitas manusia sebagai hamba, tidak ada perbedaan antara laki-laki dan perempuan. Keduanya mempunyai potensi dan peluang yang sama untuk menjadi hamba ideal, yaitu dalam Al-Qur'an biasa diistilahkan sebagai orang- orang yang bertaqwa, dan untuk mencapai derajat bertaqwa ini tidak dikenal adanya perbedaan jenis kelamin, suku bangsa atau kelompok etnis tertentu. Dalam kapasitas sebagai hamba, laki-laki dan perempuan masing-masing akan mendapatkan penghargaan dari Tuhan sesuai dengan kadar pengabdiannya (Q.S. al-Nah1/16:97).

2. Laki-Laki dan Perempuan sebagai Khalifah di bumi 


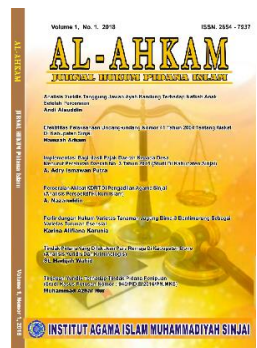

Maksud dan tujuan penciptaan manusia di muka bumi, selain untuk menjadi hamba yang tunduk dan patuh serta mengabdi kepada Allah swt, juga untuk menjadi khalifah di bumi (QS. Al-An'am/6:165). Kata Khalifah tidak menunjuk kepada salah satu jenis kelamin atau kelompok etnis tertentu. Laki-laki dan perempuan mempunyai fungsi yang sama sebagai khalifah, yang akan mempertanggungjawabkan tugas-tugas kekhalifahannya di bumi, sebagaimana halnya mereka harus bertanggung jawab sebagai hamba Tuhan.

3. Laki-laki dan perempuan menerima perjanjian primordial

Laki-laki dan perempuan sama-sama mengemban amanah dan menerima perjanjian primordial dengan Tuhan. Seperti diketahui, menjelang seorang anak manusia keluar dari rahim ibunya, ia terlebih dahulu harus menerima perjanjian dengan Tuhannya (QS. Al-A'raf/7:172). Tidak ada seorangpun anak manusia lahir di muka bumi yang tidak berikrar akan keberadaan Tuhan, dan ikrar mereka disaksikan oleh para malaikat. Tidak ada seorangpun yang mengatakan "tidak". Dalam Islam, tanggung jawab individual dan kemandirian berlangsung sejak dini, yaitu sejak dalam kandungan. Sejak awal sejarah manusia dalam Islam tidak dikenal adanya diskriminasi jenis kelamin. Laki-laki dan perempuan sama-sama menyatakan ikrar ketuhanan yang sama. Rasa percaya diri seorang perempuan dalam Islam seharusnya terbentuk sejak lahir, karena sejak awal tidak pernah diberikan beban khusus berupa "dosa warisan" seperti yang dikesankan di dalam tradisi Yahudi-Kristen, yang memberikan citra negatif begitu seseorang lahir sebagai perempuan. Dalam tradisi ini, perempuan selalu dihubungkan dengan drama kosmis, di mana Hawa dianggap terlibat di dalam kasus keluarnya Adam dari surga. Al-Qur'an yang mempunyai pandangan positif terhadap manusia, Al-Qur'an menegaskan bahwa Allah memuliakan seluruh anak cucu Adam (Q.S. Al-Isra/17:70). Dalam Al-Qur'an, tidak pernah ditemukan satupun ayat yang menunjukan keutamaan seseorang karena faktor jenis kelamin atau karena keturunan suku bangsa tertentu.

4. Adam dan Hawa terlibat aktif dalam drama kosmik

Semua ayat yang menceritakan tentang drama kosmis, yakni cerita tentang keadaan Adam dan pasangannya di surga sampai keluar ke bumi, selalu menekankan kedua belah pihak secara aktif dengan menggunakan kata ganti untuk dua orang yakni kata ganti untuk Adam dan Hawa, seperti dapat dilihat dalam beberapa kasus berikut ini: Keduanya diciptakan di surga dan memanfaatkan fasilitas surga (Q.S. Al-Baqarah/2:35); Keduanya mendapat kualitas godaan yang sama dari syaitan (Q.S. Al-A'raf/7:20); Sama- sama memakan buah khuldi dan keduanya menerima akibat jatuh ke bumi (Q.S. alA'raf/7:22); Sama-sama memohon ampun dan sama-sama diampuni Tuhan (Q.S. Al- A'raf/7:23); Sama-sama memohon ampun dan sama-sama diampuni Tuhan (Q.S. Al- A'raf/7:23); Setelah di bumi, keduanya mengembangkan keturunan dan saling melengkapi dan saling membutuhkan (Q.S. Al-Baqarah/2:187). Adam dan Hawa disebutkan secara bersama-sama sebagai pelaku dan bertanggung jawab terhadap drama kosmis tersebut. Jadi, tidak dapat dibenarkan jika ada 


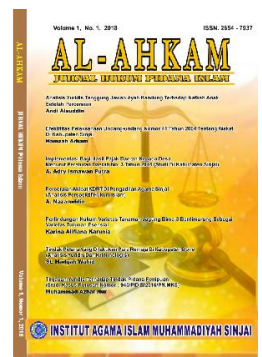

anggapan yang menyatakan perempuan sebagai mahluk penggoda yang menjadi penyebab jatuhnya anak manusia ke bumi penderitaan

5. Laki-laki dan perempuan berpotensi meraih prestasi

Dalam hal peluang untuk meraih prestasi maksimum, tidak ada perbedaan antara laki-laki dan perempuan, sebagaimana ditegaskan secara khusus di dalam tiga ayat Al- Qur'an (Q.S. Ali Imran/3:195, Q.S. An-Nisa/4:124 dan Q.S. Mu'min/40:40). Ayat-ayat ini mengisyaratkan konsep kesetaraan jender yang ideal dan memberikan ketegasan bahwa prestasi individual, baik dalam bidang spiritual maupun urusan karier profesional, tidak mesti dimonopoli oleh salah satu jenis kelamin saja. Laki-laki dan perempuan memperoleh kesempatan yang sama meraih prestasi optimal. Namun, dalam kenyataan di masyarakat, konsep ideal ini masih membutuhkan tahapan dan sosialisasi, karena masih terdapat sejumlah kendala, terutama kendala budaya yang sulit diselesaikan. Salah satu obsesi Al-Qur'an ialah terwujudnya keadilan di dalam masyarakat. (Dwi Hidayatul Firdaus, 2021)

Melihat paparan yang dikemukakan Prof.Dr. Nasaruddin Umar terlihat bahwa AlQur'an sudah memberikan keterangan bahwa perempuan dan laki-laki memiliki peran yang setara. Tetapi melihat kenyataan yang terjadi, keterangan dalam Al-Qur'an mengenai hal ini sangan bertentangan dengan realita yang ada.

Istilah Maqasid al-Syari'ah berasal dari bahasa Arab yang merupakan bentuk jamak dari kata maqsud yang berarti sasaran, niat, tujuan akhir. Maqasih al-Syari'ah terdiri dari dua kata yaitu Maqasiddan syari'ah. Maqasid yaitu tujuan atau tempat yang dituju, sedangkan syariah yang berarti jalan menuju ke arah sumber kehidupan. Secara terminologi, maqasid al-Syari'ah adalah tujuan atau rahasia yang ditetapkan oleh Syari' (Pembuat Hukum) pada setiap hukum dari hukum-hukum syari'ah (Kuat Ismanto, 2006: 125).

Konsep maqasid al-Syari'aih berangkat dari pengembangan konsep maslahah. Maslahah digunakan pada suatu perkara yang dianggap sebagai perbuatan yang memiliki kemaslahatan. Kemaslahatan manusia menjadi tujuan syara' yang dihasilkan dari pendalaman terhadap isi al-Quran dan Hadis. Menurut Asy-Syatibi, ada dua aspek yang merupakan bentuk pemeliharaan kemaslahatan manusia, yaitu aspek positif (ijabiyyah) dan aspek negatif (salbiyah).

Maslahat yang menjadi akar dari pengembangan Maqasid al-Syari'ah merupakan kajian yang sangat penting. Karena maslahat adalah tujuan pembentukan hukum yang keberlakuannya tidak mengenal tempat dan waktu. Berlaku secara global dan tidak akan pernah ketinggalan zaman.

Ada berapa pembagian maslahat yang ditinjau dari beberapa aspek yaitu:

a. Maslahat yang ditinjau dari kuantitasnya: maslahat kulliyah yaitu maslahat yang kembali kepada seluruh umat atau jamaah. Maslahah al-juz'iyyah al-khasshah yaitu maslahah perorangan atau perseorangan yang lebih sedikit.

b. Maslahah yang ditinjau dari hajat manusia yang dikenal dengan istilah kulliyah al-khamsah atau lima hajat manusia yaitu : hifdz al-din (menjaga agama), hidfz 


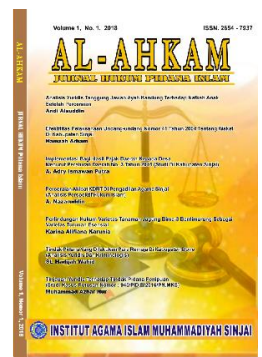

al-nafs (menjaga jiwa), hifdz al-aql (menjaga akal), hifdz al-nasl (menjaga keturunan), hifdz al-mal(menjaga harta).

c. Maslahah yang dilihat dari kekuatannya: Dharuriyah (kemaslahatan yang sangat urgen bagi kehidupan manusia dan agamanya), Hajiyat (maslahah yang dikehendaki sebagai kelapangan dan menghilangkan kesulitan), Tahsiniyah (maslahat yang dikehendaki sebagai keutamaan dalam kebaikan menurut adat dan situasi yang ada).

\section{Simpulan}

Wanita karier yang berkecimpung di ranah publik ada yang mampu menyeimbangkan perannya di ranah domestik(rumah) pula tetapi ada yang tidak mampu menyeimbangkan kedua. Bagi pasangan suami istri yang dikhawatirkan tidak mampu mampu menyeimbangkan perannya di salah satu ranah maka pilihan untuk menunda kehamilan sebagai salah satu alternatif untuk meringankan beban peran yang dijalankan wanita. Perlu diingat kembali bahwa alasan penundaan kehamilan haruslah sesuai dengan alasan yang dibenarkan agama dengan mempertimbangkan kemaslahatan bersama dan salah satu pihak terutama wanita yang akan menjalani peristiwa kehamilan/melahirkan. Alasan maslahat menjadi salah satu argumen kebolehan untuk melakukan kontrasepsi karena pada dasarnya kontrasepsi adalah pilihan terakhir jika seorang wanita mengalami suatu keadaaan yang tidak memungkinkan untuk melanjutkan dalam menghasilkan keturunan.Adapun pemakaian kontrasepsi berbentuk spiral atau dikenal dengan istilah (UID). Kontrasepsi ini bersifat temporal dan dapat dihentikan penggunaannya. Karena bersifat temporal maka penggunaan ini dibolehkan dalam Islam selagi tidak mencegah kehamilan secara permanen.

\section{Daftar Pustaka}

\section{Buku:}

Albar, Muhammad, Wanita Karier dalam Timbangan Islam, Kodrat Kewanitaan, Emansipasi dan Pelecehan Seksual, terj. Amir Hamzah Fachrudin. Jakarta:Pustaka Azzam, 1999.

Ali, Hasan, M.. Masail Fiqhiyah Al-Haditsah pada Masalah-Masalah Kontemporer Hukum Islam.Jakarta: PT Raja Grafindo Persada, 1998.

Baziad, Ali. Kontrasepsi Hormonal. Jakarta : YBP-Sarwono,2002.

Fakih, Mansour, Analis Gender dan Transformasi Sosial, Jogjakarta, Pustaka Pelajar, 2007.

Hartanto, Hanafi.Keluarga Berencana dan Kontrasepsi. Jakarta: Pustaka Sinar Harapan,2004.

Hellen, Varney, Buku Ajar Asuhan Kebidanan Edisi 4 Volume 1. Jakarta :EGC, 2006

Husain, Khairiyah, Ibu Ideal, Perananya dalam Mendidik dan Membangun Potensi Anak, Surabaya: Risalah Gusti, 2005.

Kementrian Agama Republik Indonesia, Qur'an Kemenag, https://quran.kemenag.go.id/sura/2/187 (29 Januari 2021).

Kementrian Pendidikan dan Kebudayaan, Kamus Besar Bahasa Indonesia, https://kbbi.kemdikbud.go.id/entri/karier, (29 Januari 2021).

Kuat Ismanto, Asuransi Syariah Persfektif Maqashid Syariah, Yogyakarta: Pusataka Pelajar, 2016. 


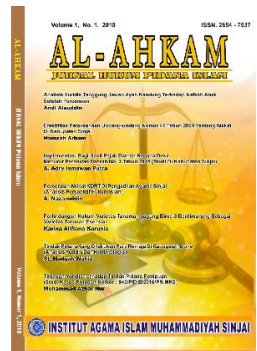

Laonso, Hamid, Muhammad Jamil, Hukum Islam Alternatif Solusi Terhadap Masalah Fiqih Kontemporer, Restu Ilahi, 2005.

Rosyadi, A. Rakhmat, Saroso Dasar, Indonesia: Keluarga Berencana ditinjau dari Hukum Islam, Bandung: Pustaka, 1986.

Sinsin, Iis. Masa Kehamilan dan Persalinan. Jakarta: PT Elex Media Komputindo, 2008 Staf Pengajar Departemen Farmakologi. Kumpulan Kuliah Farmakologi Edisi 2..Jakarta:Penerbit Buku Kedokteran EGC, $2004 .$.

Soetjiningsih.ASI: Petunjuk Untuk Tenaga Kesehatan. Jakarta: Penerbit BukuKedokteran EGC,1997.

Staf Pengajar Departemen Farmakologi. Kumpulan Kuliah Farmakologi Edisi 2. Jakarta: Penerbit Buku Kedokteran EGC,2004.

Yanggo, Huzaemah Tahido, Fikih Perempuan Kontemporer, Indonesia. Penerbit Ghalia indonesia, 2010.

Yusuf Al-Qardhawi, Halal dan Haram, Alih Bahasa: Mu'amal Hamidy, Surabaya: Bina ilmu, 1993.

\section{Jurnal Online tanpa DOI:}

Firdaus, Dwi Hidayatul, Sinkronisasi Maqasid al-Syari'ah dan Konsep Kesetaraan Gender dalam Konsep Iddah, Egalita: Jurnal Kesetaraan dan Keadilan Gender, ejurnal.uin-malang.ac.id.

Husin, Farida, Wanita Karir dalam Islam, Jurnal Ilmiah, VIII Tahun 2015 (1).

Ratna, Ikhwani, Irdayanti, Perbedaan Pengaruh Penggunaan Alat Kontrasepsi Iud Dan Suntik Terhadap Siklus Haid Perempuan Di Kecamatan Marpoyan Damai Pekanbaru, dalam Marwah: Jurnal Perempuan, Agama dan Gender; Vol 11, No 2 (2012): Juli - Desember 2012.

Wakirin, Wanita Karir dalam Perspektif Islam, Jurnal Pendidikan Islam Al-I'tibar(Vol.4 No.1) 2017.

\section{Artikel dipresentasikan dalam konferensi/seminar:}

Latifah, Nur aini, Makalah Seminar:Pemberdayaan Perempuan Sebuah Upaya Mencetak Generasi Unggulan, Tultungagung: Pusat Studi Gender STAIN Tulungagung, 2008.

Suhaedah,Pengaturan Jarak Kehamilan Menurut Al-Qurean, Skripsi, Makassar: UIN Alauddin, 2013. 